\title{
High temperature effects on the response of photosynthesis to light in sweet orange plants infected with Xylella fastidiosa
}

\author{
Rafael Vasconcelos Ribeiro ${ }^{*}$, Eduardo Caruso Machado² ${ }^{2}$, Ricardo Ferraz de Oliveira ${ }^{1}$ and Carlos Pimentel $^{3}$
}

${ }^{1}$ Departamento de Ciências Biológicas, Escola Superior de Agricultura “Luiz de Queiroz", Universidade de São Paulo, Av. Pádua Dias, 11, CP 09, 13418-900, Piracicaba, SP, Brazil. ${ }^{2}$ Centro de Ecofisiologia e Biofísica, Instituto Agronômico de Campinas, CP 28, 13001-970, Campinas, SP, Brazil. ${ }^{3}$ Instituto de Agronomia, Departamento de Fitotecnia, Universidade Federal Rural do Rio de Janeiro, 28851-970, Itaguai, RJ, Brazil.*Corresponding author: rvribeir@esalq.usp.br.

Received: 28/01/2003, Accepted: 25/04/2003

The objective of this study was to evaluate the high temperature effects on the response of photosynthesis to light in sweet orange plants infected with Xylella fastidiosa. This vascular bacterium is the causal agent of the citrus variegated chlorosis that causes severe economical losses to the Brazilian citrus industry. The responses of the photosynthetic oxygen evolution and the parameters related to chlorophyll $a$ fluorescence to the increase in light intensity were evaluated at $35^{\circ} \mathrm{C}$ and $45^{\circ} \mathrm{C}$ in both healthy and infected leaf discs. The increase in temperature affected the photosynthetic apparatus of both healthy and infected plants, although infected plants showed higher photochemical sensitivity at the higher temperature (e.g. in the potential quantum efficiency of photosystem II, maximum and basal fluorescence yield, and in the relation between variable and basal fluorescence yield). This higher sensitivity of infected plants was not reflected in the overall photosynthetic reaction, since photosynthetic oxygen evolution values did not vary at $45^{\circ} \mathrm{C}$. Healthy and infected plants showed differences in photosynthetic oxygen evolution but displayed similar effective quantum efficiency of photosystem II as well as apparent electron transport rates at $35^{\circ} \mathrm{C}$. These results suggest that the limitations in photosynthesis observed on the infected plants might arise through impaired biochemical reactions.

Key words: chlorophyll fluorescence, Citrus sinensis, light response curve, photosynthesis, temperature, Xylella fastidiosa.

Efeitos da alta temperatura na resposta da fotossíntese à luz em laranjeira doce infectada por Xylella fastidiosa: $O$ objetivo desse estudo foi avaliar os efeitos da alta temperatura nas respostas da fotossíntese à luz em laranjeira doce infectada por Xylella fastidiosa. Essa bactéria vascular é o agente causal da clorose variegada dos citros, que causa sérios problemas para a indústria citrícola brasileira. Respostas da evolução de oxigênio fotossintético e parâmetros relacionados com fluorescência da clorofila $a$ ao aumento da intensidade luminosa foram avaliadas a $35^{\circ} \mathrm{C} \mathrm{e} 45^{\circ} \mathrm{C}$, em discos foliares sadios e infectados. $\mathrm{O}$ aumento da temperatura afetou a maquinaria fotossintética das plantas sadias e infectadas, mostrando as plantas infectadas maior sensibilidade fotoquímica (i.e., na eficiência quântica potencial do fotossistema II, fluorescência máxima e basal e na relação entre fluorescência variável e basal). Essa maior sensibilidade das plantas infectadas não refletiu menores taxas de fotossíntese, uma vez que os valores da evolução de oxigênio fotossintético não mudaram a $45^{\circ} \mathrm{C}$. Plantas sadias e infectadas apresentaram diferenças na evolução de oxigênio fotossintético, mas valores similares de eficiência quântica efetiva do fotossistema II e da taxa aparente de transporte de elétrons a $35^{\circ} \mathrm{C}$. Esses resultados sugerem que a limitação da fotossíntese em plantas infectadas pela Xylella fastidiosa pode surgir de injúrias nas reações bioquímicas.

Palavras-chave: Citrus sinensis, curva de resposta à luz, fluorescência da clorofila, fotossíntese, temperatura, Xylella fastidiosa.

\section{INTRODUCTION}

Citrus variegated chlorosis (CVC) is a vascular disease, caused by the bacterium Xylella fastidiosa, which causes severe problems to the Brazilian citrus industry. Because this bacterium inhabits the xylem vessels of plants, it may induce a restriction in water flow that consequently lower shoot 
hydration (Hopkins, 1989; Purcell and Hopkins, 1996). The mechanism of pathogenicity is unclear, but among the mechanisms suggested, the blockade of the xylem vessels leading to plant water deficit is the most accepted (Hopkins, 1989; Machado et al., 1994; Purcell and Hopkins, 1996). Plants with CVC show leaf wilting, leaf variegated chlorosis that can develop into necrosis (Rossetti, 1991), low sap flow (Oliveira et al., 2000), and a decreased photosynthesis (Habermann et al., 2003; Machado et al., 1994; Ribeiro, 2002) with a consequent decrease in production.

Simultaneously to CVC disease, plants are subjected to changes in environmental conditions along their life cycle. Among these environmental factors, high temperature is a common constraint in tropical regions, causing reversible or irreversible damage to the photosynthetic apparatus (Berry and Björkman, 1980). Important high temperature effects on photosynthesis are the inactivation of thylakoid membrane reactions and damage to the enzymes involved in photosynthetic carbon metabolism (Berry and Björkman, 1980). These effects could be further aggravated if other stresses (e.g. high irradiance) are imposed concomitantly (Berry and Björkman, 1980; Laisk et al., 1998), as it frequently occurs under natural conditions.

The most productive areas in Brazil are located at the northwestern and western regions of the São Paulo State. These regions show a severe $\mathrm{CVC}$ incidence coupled to high temperatures during most of the year (Salva et al., 1995; Fundecitrus, 2002). Some authors have suggested that $X$. fastidiosa could be an occasional pathogen that causes more damage under environmental stress conditions (Machado et al., 1994; Ribeiro, 2002). In fact, the success of any CVC control strategy should consider the role of predisposition or synergistic stress factors during the disease (Hopkins, 1989). Since photosynthetic light response curves generally show unique proprieties for each species (Nilsen and Orcutt, 1996), any change in its characteristics due to stresses such as heat, high light intensity, and pathogen infection may help to determine how plants are affected.

Such studies in citrus are not available, especially in plants infected with $X$. fastidiosa that do not present any visible symptoms. The aim of the present study was to evaluate the effects of high temperature on the response of photosynthesis to light in the 'Pera' variety of sweet orange infected with $X$. fastidiosa using simultaneous measurements of photosynthetic oxygen evolution and chlorophyll $a$ fluorescence in leaf discs.

\section{MATERIALS AND METHODS}

Plant material: Measurements of photosynthetic oxygen evolution and chlorophyll $a$ fluorescence were carried out in 9 month-old seedlings of sweet orange [Citrus sinensis (L.) Osbeck cv. Pera], grown in $3 \mathrm{~L}$ plastic pots containing soil mixture (one-half soil, one-quarter sand, and one-quarter cattle manure with nitrogen-phosphate-potassium fertilizer) under greenhouse conditions (maximal and minimum air temperatures of 42 and $18^{\circ} \mathrm{C}$ respectively, minimum $\mathrm{RH}$ of $30 \%$, maximal light incidence of approximately $1,800 \mu \mathrm{mol}$ $\mathrm{m}^{-2} \cdot \mathrm{s}^{-1}$, and a photoperiod between 13.4 and $10.6 \mathrm{~h}$ ). The 'Pera' variety of sweet orange was chosen because it is the most affected by $\mathrm{CVC}$ and it is the most cultivated sweet orange in Brazil. A nutrient solution was applied every ten days (adapted from Van Raij et al., 1996) in order to ensure that no nutrient deficiencies occurred. Daily irrigations were performed during the morning hours until reaching soil saturation. Weekly pesticide applications prevented the occurrence of insects or additional disease.

Plant inoculation: The plants were divided into two groups $(n=4)$, one with healthy plants and the other with infected plants. The inoculation with $X$. fastidiosa was performed according to Almeida et al. (2001). Needle inoculation was done by probing the stem of the seedlings through a $2 \mu \mathrm{L}$ drop of bacterial suspension with a number 0 insect pin, five times. Leaves of all plants were analyzed by the polymerase chain reaction (PCR) (Minsavage et al., 1994) and by isolation and culture in periwinkle wilt-GelRite solid medium (Hill and Purcell, 1995; Almeida et al., 2001) for bacterium detection. The measurements of photosynthetic oxygen evolution and chlorophyll $a$ fluorescence started 7 months after the inoculation of $X$. fastidiosa. It is important to emphasize that infected plants did not show any visible symptoms of CVC, such as leaf chlorosis, necrosis and wilting, although the PCR and isolation results confirmed the presence of $X$. fastidiosa.

Thermal treatment: Healthy plants and X. fastidiosa-infected plants were placed in a growth chamber (E-15, Conviron, Winnipeg, Canada), with temperatures of $35 / 20^{\circ} \mathrm{C}$ (day/night), photosynthetic photon flux $(P P F)$ of $600 \mu \mathrm{mol} \cdot \mathrm{m}^{-2} \cdot \mathrm{s}^{-1}$ (provided with fluorescent tubes - Philips day-light $40 \mathrm{~W}$ ), air vapor pressure deficit of $1.0 \mathrm{kPa}$, and a photoperiod of 14 $\mathrm{h}$ for seven days. After this period, leaf discs $\left(10 \mathrm{~cm}^{2}\right)$ were excised from healthy and infected leaves. Immediately after the excision, the leaf discs were enclosed in a leaf chamber at 
$35^{\circ} \mathrm{C}$, with a wet felt disc to maintain constant leaf water status during measurements of photosynthetic oxygen evolution and chlorophyll $a$ fluorescence (Delieu and Walker, 1981). After these measurements, the leaf temperature was set to $45^{\circ} \mathrm{C}$. Leaf discs were maintained in dark conditions during $30 \mathrm{~min}$ at $45^{\circ} \mathrm{C}$ and a second set of measurements was conducted. The leaf temperatures of 35 and $45^{\circ} \mathrm{C}$ were chosen because they represent optimum and harmful temperatures, respectively, for sweet orange plants (Ribeiro et al., 2001). Leaf temperature was controlled using a water bath (MA-127, Marconi, Piracicaba, SP Brazil) and monitored with a copper-constantan thermocouple (AWG 24, Omega Eng., Stamford, CT USA) attached to the abaxial leaf disc surface.

Measurements of photosynthetic oxygen evolution: Photosynthetic oxygen evolution $(A)$ was measured with a leaf disc oxygen electrode (LD2/3 leaf chamber, Hansatech, King's Lynn, UK). $P P F$ were provided by an external light source (LS3, Hansatech) and $A$ values were recorded using the Oxygraph System Software v. 2.22 (Hansatech). The $\mathrm{CO}_{2}$ saturation concentration $(2.9 \pm 0.1 \%$ measured with a PBI Dansensor - CheckMate $9900 \mathrm{O}_{2} / \mathrm{CO}_{2}$, Ringsted, Denmark) in the chamber was generated by $0.2 \mathrm{~cm}^{3}$ of carbonate/bicarbonate buffer solution (1M, 1:19 v/v) (Delieu and Walker, 1981). Under these conditions, the photorespiration and $\mathrm{CO}_{2}$ flow limitation to chloroplasts through the stomata are practically eliminated.

Measurements of chlorophyll a fluorescence: The chlorophyll $a$ fluorescence measurements were done simultaneously with the photosynthetic oxygen evolution measurement using a modulated fluorometer (FMS1, Hansatech) adapted to the LD2/3 leaf chamber. Maximal $\left(F_{m}\right)$ and basal $\left(F_{o}\right)$ fluorescence yield were measured in dark-adapted $(30 \mathrm{~min})$ leaves, whereas steady-state $\left(F_{s}\right)$ and maximal $\left(F_{m}{ }^{\prime}\right)$ fluorescence yield were sampled under light-adapted conditions (Van Kooten and Snel, 1990). Variable fluorescence yield was determined in dark-adapted $\left(F_{v}=F_{m}\right.$ $\left.F_{\mathrm{o}}\right)$ and in light-adapted $\left(\Delta \mathrm{F}=F_{m}{ }^{\prime}-F_{\mathrm{s}}\right)$ states. $F_{\mathrm{o}}$ ' was the basal fluorescence yield after photosystem I excitation by far-red light. The parameters calculated were: potential $\left(F_{v} / F_{m}\right)$ and effective $\left(\Delta F / F_{m}{ }^{\prime}\right)$ quantum efficiency of photosystem II (PSII) (Genty et al., 1989), photochemical $\left[q_{P}=\left(F_{m}{ }^{\prime}-F_{\mathrm{S}}\right) /\left(F_{m}{ }^{\prime}-\right.\right.$ $\left.\left.F_{\mathrm{o}}{ }^{\prime}\right)\right]$ and non-photochemical $\left[N P Q=\left(F_{m}-F_{m}{ }^{\prime}\right) / F_{m}{ }^{\prime}\right]$ fluorescence quenching, and apparent electron transport rate $\left(E T R=P P F . \Delta F / F_{m}, 0.5\right.$. 0.84) (Krall and Edwards, 1992; Bilger et al., 1995). For the calculation of ETR, 0.5 was used as the fraction of excitation energy distributed to PSII, and 0.84 was used as the fraction of total light absorbed by chlorophyll. Relative excessive $P P F$ was calculated according to Bilger et al. (1995), as the difference between $F_{v} / F_{m}$ and $\Delta F / F_{m}$, normalized by $F_{\sqrt{ }} / F_{m}$. The photosynthetic apparatus stability was evaluated by the changes in $F_{o}$ and $F_{v}$ measured at 35 and $45^{\circ} \mathrm{C}$, according to Yordanov et al. (1997).

Light response curves: Light response curves of $A$ and chlorophyll $a$ fluorescence parameters were obtained varying $P P F$ values from 33 to $1,121 \mu \mathrm{mol} \cdot \mathrm{m}^{-2} \cdot \mathrm{s}^{-1}$, at 35 and $45^{\circ} \mathrm{C}$. Prior to the photosynthesis measurements, leaf discs were kept under dark conditions for $30 \mathrm{~min}$, and then subjected to low radiation $\left(128 \mu \mathrm{mol} . \mathrm{m}^{-2} \cdot \mathrm{s}^{-1}\right)$ for $10 \mathrm{~min}$ in order to induce photosynthesis (Walker, 1990). After this period, PPF was decreased to 33 and a gradual increase was done until reaching $1,121 \mu \mathrm{mol} . \mathrm{m}^{-2} \cdot \mathrm{s}^{-1}$.

Statistical analysis: The experiment was arranged in a randomized block design with three replicates. All results were subjected to ANOVA followed by Tukey test at the 0.05 probability level in order to determine the statistical significance between healthy and infected plants, leaf temperatures, and $P P F$ levels.

\section{RESULTS AND DISCUSSION}

At the temperature of $35^{\circ} \mathrm{C}$, healthy plants showed higher values of $A$ than $X$. fastidiosa-infected ones, mainly at high irradiation levels (figure 1A). However, at $45^{\circ} \mathrm{C}, A$ values of healthy and infected leaves were quite similar, since the $A$ curve of infected plants was not significantly modified. For healthy plants, the maximal $A$ rates decreased when compared to the measurements obtained at $35^{\circ} \mathrm{C}$ (figure 1B). According to Laisk et al. (1998), the decrease in net photosynthesis at high temperatures is partially caused by a faster increase in respiration in relation to photosynthesis. In addition, at high temperature, the Rubisco affinity for $\mathrm{O}_{2}$ increases when compared to the affinity for $\mathrm{CO}_{2}$, thereby causing a reduction in photosynthesis through higher rates of RuBP oxygenation (Bernacchi et al., 2000).

The chlorophyll fluorescence yield in the dark-adapted state was also affected by temperature. No differences were found in these fluorescence parameters between healthy and infected plants (table 1), except for $F_{m}$ that showed higher values in infected plants at $35^{\circ} \mathrm{C}(\mathrm{p}<0.05)$. The $F_{v} / F_{m}$ value reflects the potential quantum efficiency of PSII and it is used 
as a sensitive indicator of plant photosynthetic performance (Björkman and Demmig, 1987). The decrease in this value coupled to the $F_{o}$ increase for either healthy or infected plants
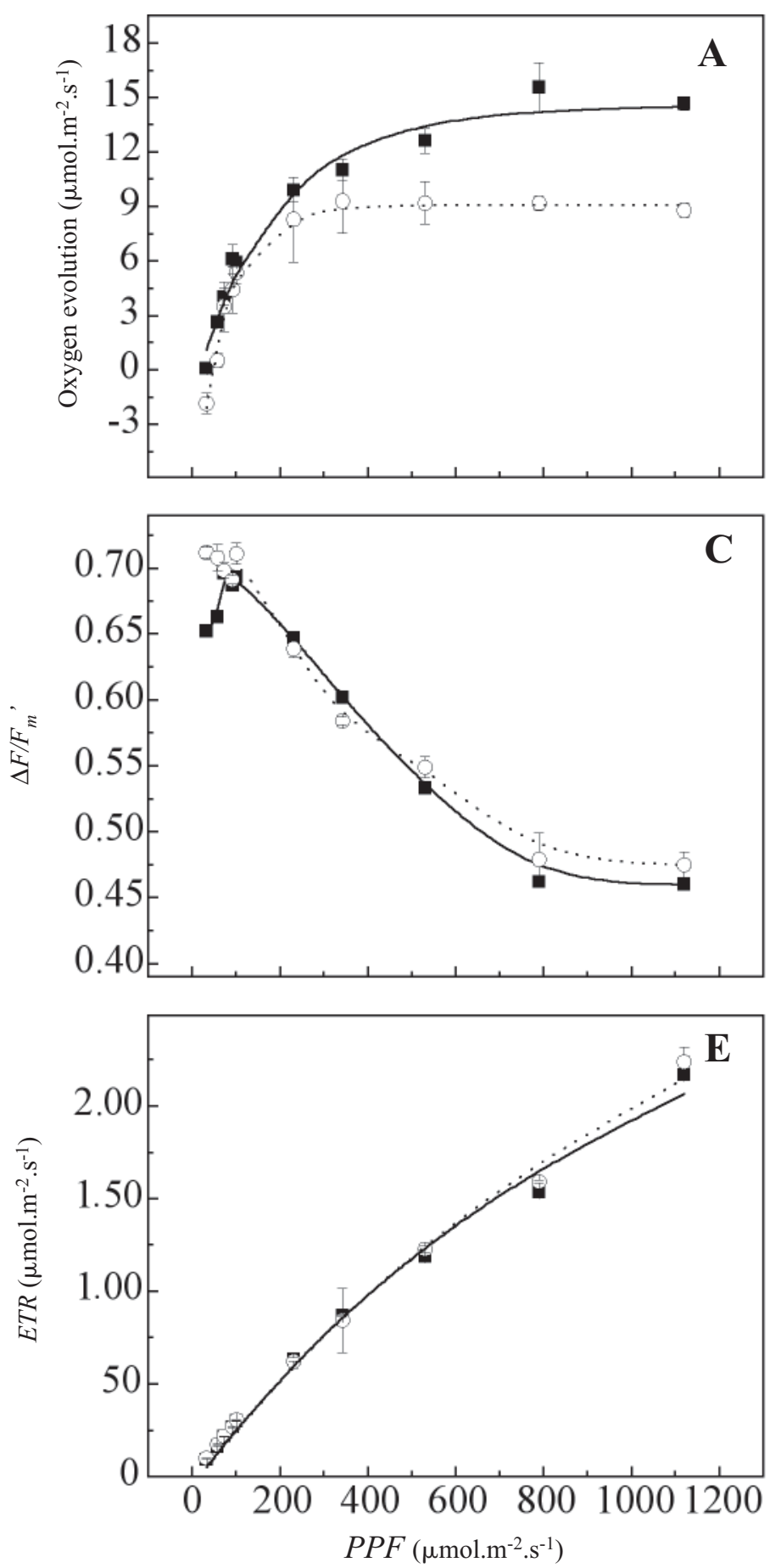

(table 1) at $45^{\circ} \mathrm{C}$ suggest the occurrence of photoinhibitory damage in response to high temperature (Maxwell and Johnson, 2000).
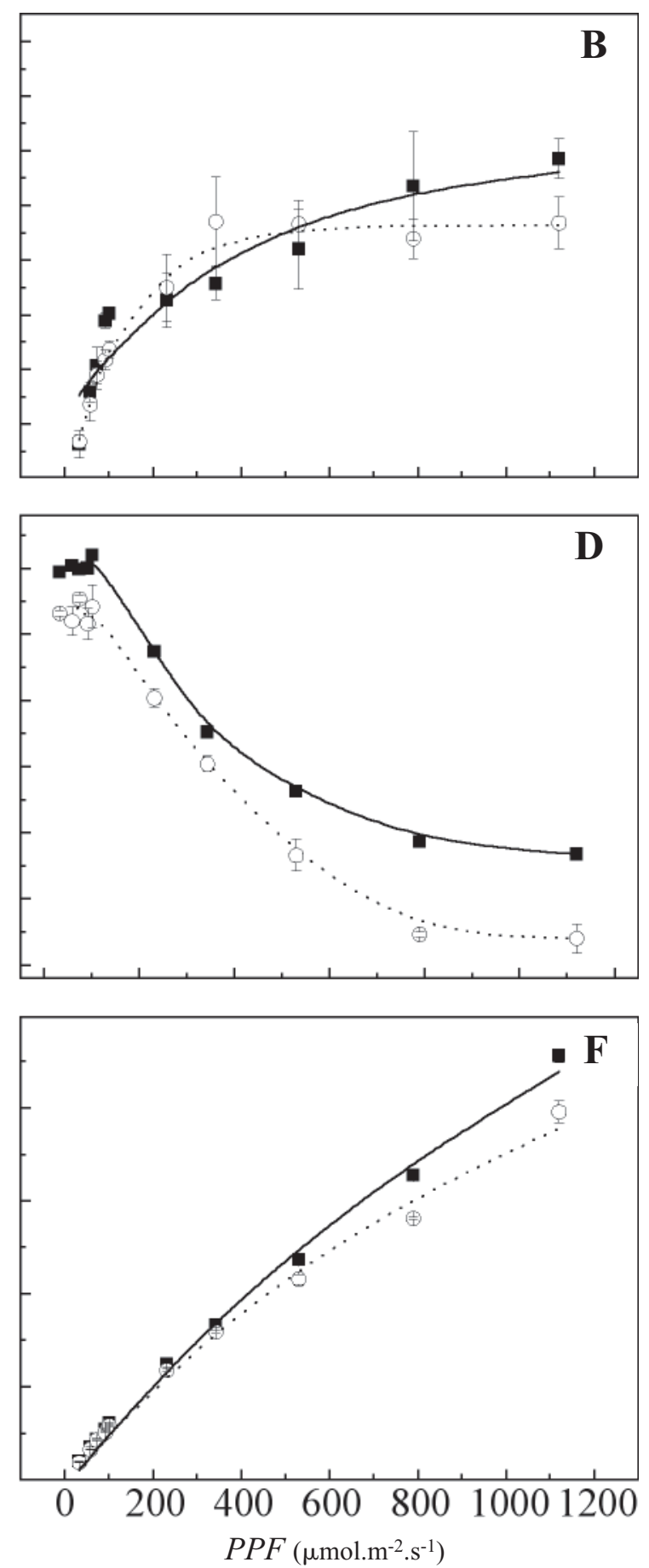

Figure 1. Temperature effects on light response of photosynthesis related parameters of healthy (closed symbols) and X. fastidiosainfected (open symbols) plants: photosynthetic oxygen evolution (A and B), effective quantum efficiency of PSII, $\Delta F / F_{m}$ ' $(\mathrm{C}$ and $\mathrm{D})$, and apparent electron transport rate, ETR (E and F). Measurements were done at leaf temperatures of $35^{\circ} \mathrm{C}(\mathrm{A}, \mathrm{C}$ and $\mathrm{E})$ and $45^{\circ} \mathrm{C}(\mathrm{B}, \mathrm{D}$ and $\mathrm{F})$. Bars represent the mean standard deviation $(\mathrm{n}=3)$. $P P F$ is the photosynthetic photon flux. 
Table 1. Temperature effects on the potential quantum efficiency of PSII $\left(F_{v} / F_{m}\right)$, maximum $\left(F_{m}\right)$ and basal $\left(F_{o}\right)$ fluorescence yield, and relation between variable and basal fluorescence yield $\left(F_{v} / F_{o}\right)$ of healthy and $X$. fastidiosa-infected sweet orange, cv. 'Pera'.

\begin{tabular}{lccccc}
\hline \multirow{2}{*}{ Plant } & \multirow{2}{*}{$\mathrm{T}_{\mathrm{L}}{ }^{\mathrm{b}}$} & \multicolumn{4}{c}{ Chlorophyll $a$ fluorescence parameters ${ }^{\mathrm{a}}$} \\
\cline { 3 - 6 } & & $F_{v} / F_{m}$ & $F_{m}$ & $F_{o}$ & $F_{v} F_{o}$ \\
\hline \multirow{2}{*}{ Healthy } & $35^{\circ} \mathrm{C}$ & $0.779 \pm 0.002 \mathrm{a}$ & $331 \pm 7 \mathrm{a}$ & $73 \pm 2 \mathrm{~b}$ & $3.53 \pm 0.04 \mathrm{a}$ \\
& $45^{\circ} \mathrm{C}$ & $0.739 \pm 0.032 \mathrm{~b}$ & $322 \pm 9 \mathrm{a}$ & $84 \pm 8 \mathrm{a}$ & $2.87 \pm 0.47 \mathrm{~b}$ \\
Infected & $35^{\circ} \mathrm{C}$ & $0.809 \pm 0.014 \mathrm{a}$ & $362 \pm 7 \mathrm{a}$ & $69 \pm 6 \mathrm{~b}$ & $4.27 \pm 0.38 \mathrm{a}$ \\
& $45^{\circ} \mathrm{C}$ & $0.717 \pm 0.014 \mathrm{~b}$ & $327 \pm 6 \mathrm{~b}$ & $93 \pm 6 \mathrm{a}$ & $2.54 \pm 0.18 \mathrm{~b}$ \\
\hline
\end{tabular}

${ }^{\mathrm{a}}$ Data represent means $\pm \mathrm{SD}$ ( $\mathrm{n}=3$ from separate plants). Different letters express significant difference for temperature treatments (Tukey's test, $p \leq 0.05$ ). ${ }^{\mathrm{b}} \mathrm{T}_{\mathrm{L}}$ is the leaf temperature treatment.

The $F_{o}$ is related to the loss of the excitation energy during its transfer from the pigment bed to reaction centers, and the $F_{v} / F_{o}$ is an indicator for the electron transport chain state and effectiveness (Yordanov et al., 1997). Thus, the main cause of the increase in $F_{o}$ induced by heat stress would be the reduction in migration efficiency of the excitation energy to PSII reaction centers (Krause and Weis, 1984; Yordanov et al., 1997). Yordanov et al. (1997) found similar decreases in $F_{v} / F_{o}$ due to an increase in temperature in sunflower and maize plants.

Concerning the damage promoted by heat stress in the photochemical apparatus, the relation between the variable fluorescence measured at 35 and $45^{\circ} \mathrm{C}\left[F_{v}\left(35^{\circ} \mathrm{C}\right) / F_{v}\left(45^{\circ} \mathrm{C}\right)\right]$ is another criterion that can be used to evaluate the photochemical stability and, especially, the stability of the system of oxygen evolution under stress conditions (Yordanov et al., 1997). These authors have shown that the relation between the basal fluorescence measured at 35 and $45^{\circ} \mathrm{C}$ $\left[F_{o}\left(35^{\circ} \mathrm{C}\right) / F_{o}\left(45^{\circ} \mathrm{C}\right)\right]$ can also be used as a criterion of the stability of LHCII. High $F_{v}\left(35^{\circ} \mathrm{C}\right) / F_{v}\left(45^{\circ} \mathrm{C}\right)$ and low $F_{o}\left(35^{\circ} \mathrm{C}\right) /$ $F_{o}\left(45^{\circ} \mathrm{C}\right)$ indicate the photochemical susceptibility to stress conditions (Yordanov et al., 1997), which we observed in infected plants (table 2).

Table 2. Effects of $X$. fastidiosa infection on the relation between basal $\left(F_{o}\right)$ and variable $\left(F_{v}\right)$ fluorescence yield of 'Pera' sweet orange measured at 35 and $45^{\circ} \mathrm{C}$.

\begin{tabular}{lcc}
\hline \multirow{2}{*}{ Plants } & \multicolumn{2}{c}{ Chlorophyll $a$ fluorescence relations ${ }^{\mathrm{a}}$} \\
\cline { 2 - 3 } & $F_{o}\left(35^{\circ} \mathrm{C}\right) / F_{o}\left(45^{\circ} \mathrm{C}\right)$ & $F_{v}\left(35^{\circ} \mathrm{C}\right) / F_{v}\left(45^{\circ} \mathrm{C}\right)$ \\
\hline Healthy & $0.87 \pm 0.07 \mathrm{a}$ & $1.09 \pm 0.09 \mathrm{~b}$ \\
Infected & $0.74 \pm 0.03 \mathrm{~b}$ & $1.25 \pm 0.02 \mathrm{a}$ \\
\hline
\end{tabular}

aData represent means \pm SD ( $n=3$ from separate plants). Different letters express significant difference between healthy and infected plants (Tukey's test, $p \leq 0.05)$.
This smaller photochemical stability of infected plants when submitted to heat stress conditions was not confirmed by the light response curve of $A$, which was not modified with increasing temperature (figures $1 \mathrm{~A}$ and $1 \mathrm{~B}$ ). Thus, it is suggested that the photochemical reactions did not limit photosynthesis in plants infected with $X$. fastidiosa at high temperature.

We also noted that the increase in $P P F$ was accompanied by a decrease in effective quantum efficiency of PSII $(\triangle F /$ $F_{m}{ }^{\prime}$ ) at both leaf temperatures (figures $1 \mathrm{C}$ and 1D). High values of $\Delta F / F_{m}$ ' in healthy plants were more evident at $45^{\circ} \mathrm{C}$ $(p \leq 0.05)$, where infected plants presented a significant decrease in this parameter (figure 1D). At low irradiation levels (until $120 \mu \mathrm{mol} . \mathrm{m}^{-2} \cdot \mathrm{s}^{-1}$ ), a higher efficiency was maintained at both temperatures for both healthy and infected plants. The relation $\Delta F / F_{m}$ ' provided a measure of the proportion of the light absorbed by the chlorophyll associated with PSII that is used in photochemistry; PSII is considered an important sensitive target to environmental stresses (Maxwell and Johnson, 2000). Thus, the decline in $\Delta F / F_{m}$, due to increasing $P P F$ may reflect a closure of the reaction centers as well as processes of dissipation of radiationless energy (Medina et al., 2002), the former indicated by $q_{P}$ and the latter by $N P Q$ values (figure 2).

ETR was not affected by temperature (figures $1 \mathrm{E}$ and $1 \mathrm{~F}$ ) and marginally affected by $X$. fastidiosa infection at $45^{\circ} \mathrm{C}$, mostly for $P P F$ higher than $500 \mu \mathrm{mol} . \mathrm{m}^{-2} . \mathrm{s}^{-1}$. The highest ETR values were found at high light intensities in healthy plants $(p \leq 0.05)$ at $45^{\circ} \mathrm{C}$, with a linear increase up to 600 $\mu \mathrm{mol} . \mathrm{m}^{-2} \cdot \mathrm{s}^{-1}$ and an absence of saturation at the highest $P P F$ levels used (figures $1 \mathrm{E}$ and $1 \mathrm{~F}$ ).

Fluorescence quenching was affected by temperature and by infection with $X$. fastidiosa (figure 2 ). The $q_{P}$ val- 
ues decreased as the $P P F$ increased (figures $2 \mathrm{~A}$ and $2 \mathrm{~B}$ ). Such decrease was stronger in infected plants than in healthy ones at $35^{\circ} \mathrm{C}$; however, no significant differences were found between healthy and infected plants at $45^{\circ} \mathrm{C}$ (figures $2 \mathrm{~A}$ and $2 \mathrm{~B}$ ). The smallest values of $q_{P}$ at $35^{\circ} \mathrm{C}$ were approximately 0.80 and 0.67 for healthy and infected plants, respectively.

According to Maxwell and Johnson (2000), while $\Delta F$ / $F_{m}$ ' is the proportion of absorbed energy being used in photochemistry, $q_{P}$ gives an indication of the proportion of opened PSII reaction centers. Therefore, $\Delta F / F_{m}$ ' is related to the achieved efficiency, while the values of $q_{P}$ and $F_{v} / F_{m}$ provide information about the underlying processes which have efficiency changed. In our case, the increased light intensity caused a decrease in $q_{P}$ of both healthy and infected plants
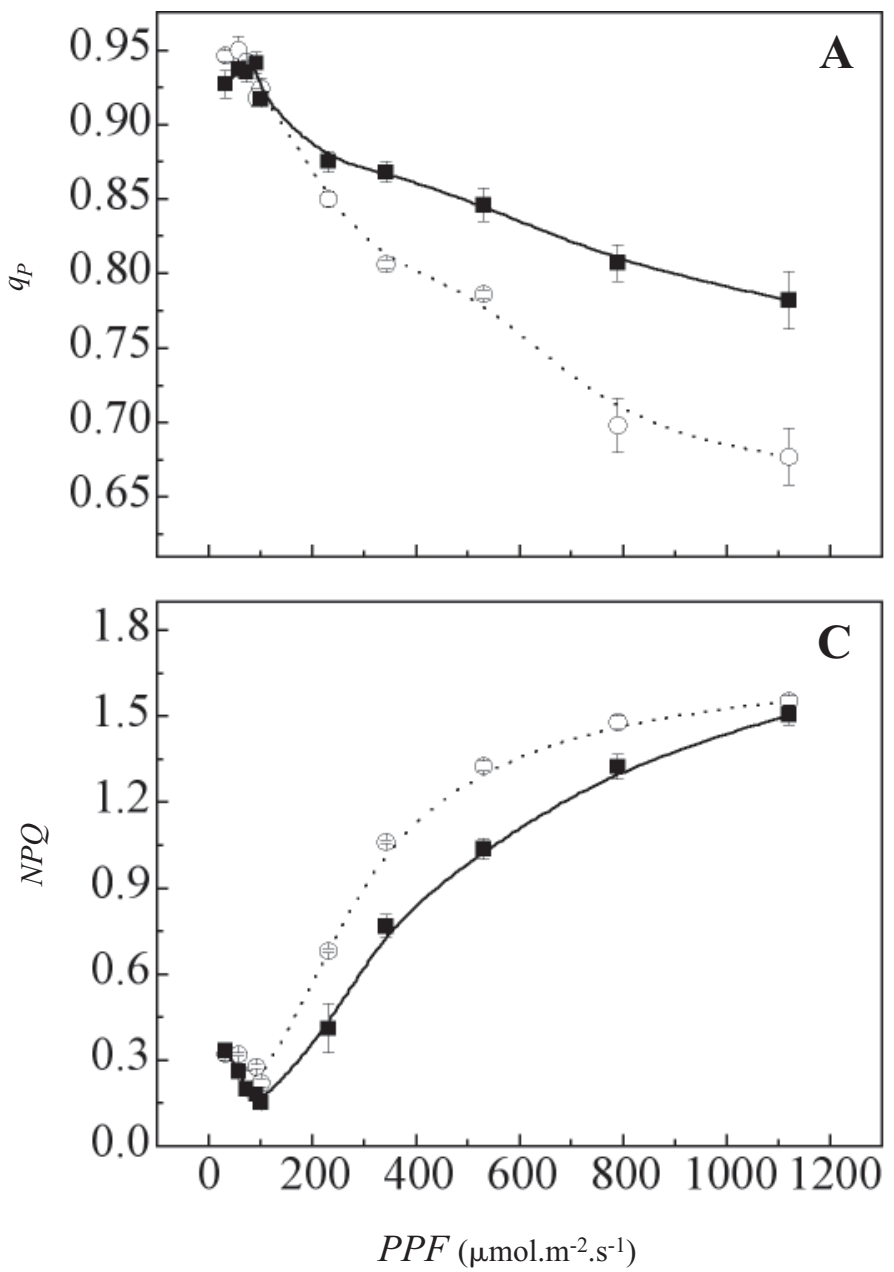

due to the closure of reaction centers, resulting from light saturation of photosynthesis (Maxwell and Johnson, 2000). The decrease of $q_{P}$ coupled to the increase in $P P F$ is associated to the accumulation of electrons at the PSII acceptor side (Schreiber and Bilger, 1987).

It is known that heat stress influences some characteristics of PSII and, consequently, the photochemical reactions of photosynthesis (Larcher et al., 1990). Nevertheless, in this study, the changes in the photochemical characteristics in relation to an increase in temperature were not the main responsible factors for the differences observed between healthy and infected plants; it would seem that plants infected with $X$. fastidiosa were insensible to the increase in temperature, since we found similar values of $A$ at $45^{\circ} \mathrm{C}$ (figures $1 \mathrm{~A}$ and 1B).
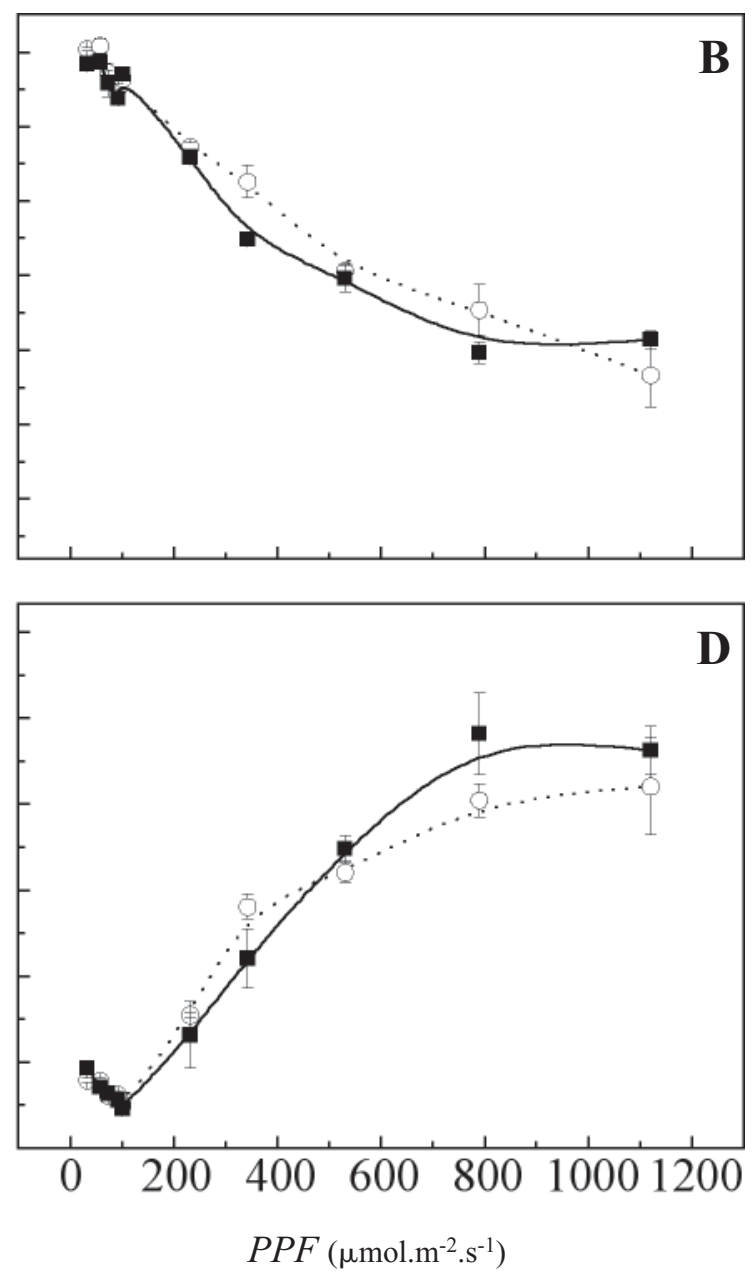

Figure 2. Temperature effects on light response of photosynthesis related parameters of healthy (closed symbols) and $X$. fastidiosa-infected (open symbols) plants: photochemical fluorescence quenching, $q_{P}(\mathrm{~A}$ and $\mathrm{B}$ ), and non-photochemical fluorescence quenching, $N P Q(\mathrm{C}$ and $\mathrm{D})$. Measurements were done at leaf temperatures of $35^{\circ} \mathrm{C}(\mathrm{A}$ and $\mathrm{C})$ and $45^{\circ} \mathrm{C}(\mathrm{B}$ and D). Bars represent the mean standard deviation $(\mathrm{n}=3) . P P F$ is the photosynthetic photon flux. 
The increase in $P P F$ provoked a rise in non-photochemical fluorescence quenching $(N P Q)$, which was somewhat higher in infected plants only at $35^{\circ} \mathrm{C}$ (figures $2 \mathrm{C}$ and 2D); at that temperature, we observed significant differences between healthy and infected plants already at low $P P F$. The high temperature treatment caused a decrease in $N P Q$ of infected plants and, thus, no differences between healthy and infected plants were found at $45^{\circ} \mathrm{C}$ (figures $2 \mathrm{D}$ ). Changes in $N P Q$ were related to alterations in the efficiency of heat dissipation relative to the dark-adapted state (Maxwell and Johnson, 2000).

The temperature of $45^{\circ} \mathrm{C}$ caused a reduction in heat dissipation $(N P Q)$ only in infected plants. Usually, the main contributor to $N P Q$ is termed high energy state quenching and it is thought to be essential in protecting the leaf from light-induced damage (Horton et al., 1996). This process requires the presence of a low $\mathrm{pH}$ in the lumen of the thylakoid and could also involve the light-induced formation of the photoprotective carotenoid, zeaxanthin (Demmig-Adams and Adams, 1992). Thus, the observed increase in $N P Q$ could be due to processes that protect the leaf from light-induced impairments or from damage of the PSII reaction center itself (Maxwell and Johnson, 2000); both processes lead to a decrease in PSII photochemistry, which was observed in $F_{v}$ $F_{m}$ and $\Delta F / F_{m}$ '

Under low light intensities (lower than $150 \mu \mathrm{mol} \cdot \mathrm{m}^{-2} \cdot \mathrm{s}^{-1}$ ), both healthy and infected plants showed high levels of $q_{P}$ and small values of $N P Q$ (figure 2). Since citrus plants have low light saturation levels, the whole photosynthetic apparatus is believed to function better at low $P P F$, thus avoiding photoinhibition and other consequent deleterious effects promoted by high PPF (Medina et al., 2002).

A linear relationship between the relative excessive $P P F$ and $N P Q$, as proposed by Bilger et al. (1995), was found in both healthy and infected plants at both leaf temperatures (figure 3). The temperature of $45^{\circ} \mathrm{C}$ caused the highest $N P Q$ values, especially on infected plants, with an excessive $P P F$ of approximately 0.18 (figure 3 ). The high correlation between $N P Q$ and excessive $P P F$ is a consequence of the regulatory mechanisms in the chloroplasts of higher plants that maintain the fluorescence yield relatively constant under most conditions (Bilger et al., 1995).

The highest photosynthetic rates of healthy plants at $35^{\circ} \mathrm{C}$ agrees with the higher $q_{P}$, and smaller $N P Q$ values, though it was evident that the photochemical reactions of photosynthesis, indicated by chlorophyll $a$ fluorescence parameters, were not responsible for the large differences of
$A$ observed between healthy and infected plants. Although healthy and infected plants have shown similar values of $\Delta F /$ $F_{m}$ ' and $E T R$ at $35^{\circ} \mathrm{C}, A$ values were significantly different above $200 \mu \mathrm{mol} . \mathrm{m}^{-2} \cdot \mathrm{s}^{-1}$, suggesting the existence of biochemical limitations on photosynthesis in plants infected with $X$. fastidiosa. We have found a clear reduction in the in vivo estimation of carboxylation efficiency in CVC-affected sweet oranges (Habermann et al., unpublished data).

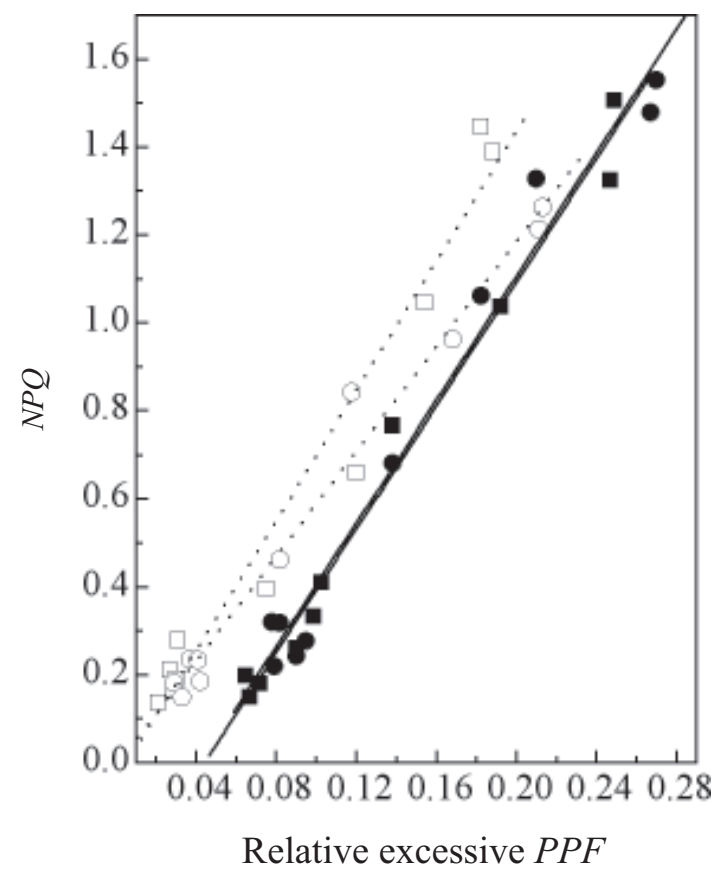

Figure 3. Temperature effects on non-photochemical fluorescence quenching $(N P Q)$ of healthy (squares) and $X$. fastidiosa-infected (circles) plants in relation to relative excessive $P P F$. Measurements were done at leaf temperatures of $35^{\circ} \mathrm{C}$ (closed symbols) and $45^{\circ} \mathrm{C}$ (open symbols). Each point represents the mean value of $N P Q(\mathrm{n}=3)$.

It is important to note that all photosynthetic responses were obtained from leaf discs without any visual symptoms, which indicated that CVC causes photosynthetic injuries prior to the development of external symptoms. Esau (1948) reported that the gum deposition in xylem vessels of grapevine with Pearce's disease and peaches with Phony peach, both caused by $X$. fastidiosa, was the first internal disease symptom and could cause photosynthetic limitations (Machado et al., 1994; Ribeiro, 2002; Habermann et al., 2003). This deposition in addition to the increase in tylosis formation occurred before the development of visual symptoms. Machado et al. (1994) and Oliveira et al. (2000) also reported low photosynthesis and low sap flow of sweet orange plants with early CVC symptoms, respectively. 
Summarizing, the photosynthesis of plants infected with $X$. fastidiosa seems to be affected by impairments on biochemical reactions at $35^{\circ} \mathrm{C}$. Infected plants showed a higher photochemical sensitivity at $45^{\circ} \mathrm{C}$, although the increase in temperature did not affect photosynthetic oxygen evolution.

Acknowledgements: R.V.R. is grateful to FAPESP(Fundação de Amparo à Pesquisa do Estado de São Paulo, Brazil, proc. 98/16259-1 and 00/02325-4) and E.C.M and C.P. to CNPq (Conselho Nacional de Desenvolvimento Científico e Tecnológico, Brazil) for fellowships granted.

\section{REFERENCES}

Almeida RPP, Pereira EF, Purcell AH, Lopes JRS (2001) Multiplication and movement of a citrus strain of Xylella fastidiosa within sweet orange. Plant Dis. 85:382-386.

Bernacchi CJ, Singsaas EL, Pimentel C, Portis AR, Long SP (2000) Improved temperature response functions for models of rubisco-limited photosynthesis. Plant Cell Environ. 24:253-259.

Berry JA, Björkman O (1980) Photosynthetic response and adaptation to temperature in higher plants. Annu. Rev. Plant Physiol. 31:491-543.

Bilger W, Schreiber U, Bock M (1995) Determination of the quantum efficiency of photosystem II and nonphotochemical quenching of chlorophyll fluorescence in the field. Oecologia 102:425-432.

Björkman O, Demmig B (1987) Photon yield of $\mathrm{O}_{2}$ evolution and chlorophyll fluorescence characteristics at $77 \mathrm{~K}$ among vascular plants of diverse origins. Planta 170:489-504.

Delieu T, Walker DA (1981) Polarographic measurement of photosynthetic oxygen evolution by leaf discs. New Phytol. 89:165-178.

Demmig-Adams B, Adams III WW (1992) Photoprotection and other responses of plants to high light stress. Annu. Rev. Plant Physiol. Plant Mol. Biol. 43:599-626.

Esau K (1948) Anatomic effects of the viruses of pierce's disease and phony peach. Hilgardia 18:423-482.

Fundecitrus (2002) Estatísticas CVC. http:// www.fundecitrus.com.br/escvcbr.htm

Genty B, Briantais JM, Baker NR (1989) The relationship between the quantum yield of photosynthetic electron transport and quenching of chlorophyll fluorescence. Biochim. Biophys. Acta 990:87-92.

Habermann G, Machado EC, Rodrigues JD, Medina CL (2003) Gas exchanges rates at different vapor pressure deficits and water relations of 'Pera' sweet orange plants with citrus variegated chlorosis. Sci. Hortic. 98:233-245.
Hill BL, Purcell AH (1995) Multiplication and movement of Xylella fastidiosa within grapevine and 4 other plants. Phytopathology 85:1368-1372.

Hopkins DL (1989) Xylella fastidiosa: xylem-limited bacterial pathogen of plants. Annu. Rev. Phytopathol. 27:271-290.

Horton P, Ruban AV, Walters RG (1996) Regulation of light harvesting in green plants. Annu. Rev. Plant Physiol. Plant Mol. Biol. 47:655-684.

Krall JP, Edwards GE (1992) Relationship between photosystem II activity and $\mathrm{CO}_{2}$ fixation in leaves. Physiol. Plant. 86:180-187.

Krause GH, Weis E (1984) Chlorophyll fluorescence as a tool in plant physiology. II. Interpretation of fluorescence signals. Photosynth. Res. 5:139-157.

Krause GH, Weis E (1991) Chlorophyll fluorescence and photosynthesis: the basics. Annu. Rev. Plant Physiol. Plant Mol. Biol. 42:313-349.

Laisk A, Rasulov BH, Loreto F (1998) Thermoinhibition of photosynthesis as analyzed by gas exchange and chlorophyll fluorescence. Russian J. Plant Physiol. 45:412-421.

Larcher W, Wagner J, Thammathaworn A (1990) Effects of superimposed temperature stress on in vivo chlorophyll fluorescence of Vigna unguiculata under saline stress. J. Plant Physiol. 136:92-102.

Machado EC, Quaggio JA, Lagôa AMMA, Ticelli M, Furlani PR (1994) Trocas gasosas e relações hídricas em laranjeiras com clorose variegada dos citros. Rev. Bras. Fisiol. Veg. 6:53-57.

Maxwell K, Johnson GN (2000) Chlorophyll fluorescence a practical guide. J. Exp. Bot. 51:659-668.

Medina CL, Souza RP, Machado EC, Ribeiro RV, Silva JAB (2002) Photosynthetic response of citrus grown under reflective aluminized polypropylene shading nets. Sci. Hortic. 96:115-125.

Minsavage GV, Thompson CM, Hopkins DL, Leite RMVBC, Stall RE (1994) Development of a polymerase chainreaction protocol for detection of Xylella fastidiosa in plant tissue. Phytopathology 84:456-461.

Nilsen ET, Orcutt DM (1996) The physiology of plants under stress: abiotic factors. John Wiley, New York.

Oliveira RF, Machado EC, Marin FR, Medina CL (2000) Sap flow rates and stomatal conductance of sweet orange 'Pêra' (Citrus sinensis L. Osb.). In: Proceedings of the IX International Society of Citriculture Congress, Orlando, USA, pp.391.

Purcell AH, Hopkins DL (1996) Fastidious xylem-limited bacteri al plant pathogens. Annu. Rev. Phytopathol. $34: 131-151$.

Ribeiro RV (2002) Influência da temperatura na fotossíntese de laranjeira 'Pera' com clorose variegada dos citros. Piracicaba, Escola Superior de Agricultura "Luiz de Queiroz", Universidade de São Paulo, MSc. thesis. 
Ribeiro RV, Machado EC, Oliveira RF, Medina CL (2001) Resposta da fotossíntese à temperatura e sua interação com a intensidade luminosa em mudas de laranjeira 'Pera'. In: Annals of the VIII Congresso Brasileiro de Fisiologia Vegetal. Ilhéus, Brazil, pp.211.

Rossetti V (1991) Clorose variegada dos citros (CVC). In: Rodrigues O, Viégas F, Pompeu Jr J, Amaro AA (eds), Citricultura brasileira, pp.715-721. Fundação Cargill, Campinas.

Salva RA, Roberto RS, Carlos EF (1995) Situação da clorose variegada dos citros no Estado de São Paulo. Laranja 16:155-164.

Schreiber U, Bilger W (1987) Rapid assessment of stress effects on plant leaves by chlorophyll fluorescence measurements. In: Tenhunen JD, Catarino FM, Lange OL, Oechel WC (eds), Plant response to stress, pp.2753. Springer-Verlag, Berlin.
Van Kooten O, Snel JFH (1990) The use of chlorophyll fluorescence nomenclature in plant stress physiology. Photosynth. Res. 25:147-150.

Van Raij B, Cantarella H, Quaggio JA, Furlani AMC (1996) Recomendações de adubação e calagem para o Estado de São Paulo. Instituto Agronômico \& Fundação IAC, Campinas.(Boletim Técnico, 100)

Walker DA (1990) Use of the oxygen electrode and fluorescence probes in simple measurements of photosynthesis. Oxygraphics Ltda, Chichester.

Yordanov I, Tsonev T, Goltsev V, Kruleva L, Velikova V (1997) Interactive effect of water deficit and high temperature on photosynthesis of sunflower and maize plants. 1. Changes in parameters of chlorophyll fluorescence induction kinetics and fluorescence quenching. Photosynthetica 33:391-402. 